\title{
Recent rainfall-induced landslides and debris flow in northern Taiwan
}

\author{
Hongey Chen ${ }^{\mathrm{a}, *}$, Simon Dadson ${ }^{\mathrm{b}}$, Yi-Guan $\mathrm{Chi}^{\mathrm{c}}$ \\ ${ }^{a}$ Department of Geosciences, National Taiwan University, No. 1, Section 4, Roosevelt Road, Taipei, Taiwan \\ ${ }^{\mathrm{b}}$ Department of Earth Sciences, Cambridge University, Downing Street, Cambridge CB2 3EQ, United Kingdom \\ c Syzygy Information Service Company, Taipei, Taiwan
}

Received 19 February 2004; received in revised form 23 September 2005; accepted 4 January 2006

Available online 7 February 2006

\begin{abstract}
This paper discusses the factors initiating landslides and a large-scale debris flow in the Chonho area of Taipei County, northern Taiwan, which resulted from heavy rainfall during Typhoon Xangsane in November 2000. The morphology and triggering mechanism of the landslides and the debris flow were investigated using aerial photographs taken over the past 20 years, field measurement of channel cross-sections, laboratory assessment of slope material properties, and slope stability analysis. A large landslide that occurred in the source area was the initial source of material for the debris flow. The majority of the landslide debris entered the main stream, where it mixed with water and became a debris flow. Eroding the sidewalls of the stream, the debris flow entrained additional material and traveled downstream into Chonho Village. Our findings indicate that the November 2000 landslides and the debris flow were strongly influenced by the physical properties of the underlying pyroclastic substrate and the pattern of bedrock discontinuities within the valleys.

Published by Elsevier B.V.
\end{abstract}

Keywords: Debris flow; Bedrock discontinuity; Landslide; Volcanic rocks; Taiwan

\section{Introduction}

Debris flows and landslides may lead to large-scale natural hazards, and may contribute to a large fraction of long-term sediment yields from mountain areas like Taiwan (Dadson et al., 2004). It is widely recognized that hillslope instability can be caused by increased subsurface pore pressures during periods of intense rainfall (Anderson and Sitar, 1995; Iverson et al., 1997), which reduce the shear strength of hillslope materials

\footnotetext{
* Corresponding author. Fax: +886223636095.

E-mail address: hchen@ntu.edu.tw (H. Chen).
}

(Keefer et al., 1984; Chen et al., 1995). A number of recent studies have demonstrated that rainfall-induced landslides can be transformed into debris flows as they move downslope (e.g., Fleming et al., 1989; Dai et al., 1999; Montgomery et al., 2000; Marchi et al., 2002; Guzzetti et al., 2004). Landslide-induced debris flows, therefore, present a hazard that is being increasingly recognized, and geological and geomorphological information on such mass movements and their causing or contributing factors form a vital component of natural hazard planning (Rib and Liang, 1978).

Until now, few detailed case studies of landslidetriggered debris flows have been presented in the literature. In this paper, we present a detailed account 
of a recent debris flow in Taiwan and describe quantitative morphological and geotechnical observations that reveal the triggering mechanism and geomorphological evolution of the landslide and debris flow. Taiwan has undergone frequent destructive typhoons throughout its history (Chang, 1996), many of which have caused landslides and debris flows (Chen et al., 1999; Chen and Su, 2001; Hung et al., 2002). During the 1990s, several typhoons caused a number of landslides and debris flows, which led to serious damage. Hazardous landslides and debris flow were triggered by (1) Typhoon Ophelia (June 1990) in eastern Taiwan, (2) Typhoon Herb (August 1996) in central Taiwan, (3) Typhoon Zebert (October 1998) in northern Taiwan, and (4) Typhoon Xangsane (November 2000) also in northern Taiwan (Central Weather Bureau, 2003).

The landslides and debris flow that forms the subject of the present paper occurred on November 1, 2000, when $774 \mathrm{~mm}$ of rain fell in a single day in the Chonho area of the Chingshan district, in the eastern part of
Taipei County, northern Taiwan (Fig. 1). The rainfall was particularly intense in northern Taipei, with a maximum hourly precipitation of $70 \mathrm{~mm}$. The Chonho debris flow, which resulted from one of the landslides, traveled over $1.5 \mathrm{~km}$ down the narrow Sanho stream, leaving an obvious disruption surface that ranged from 8 to $45 \mathrm{~m}$ in width. Finally, debris covered the entire area of Chonho Village, destroyed around thirty houses, and left the village isolated for approximately $30 \mathrm{~h}$.

Before this debris flow, the underlying Pleistocene volcanic bedrock had been considered stable, even under intense precipitation. The main aim of the present study is to discuss factors controlling the location and initiation of the landslides and the debris flow based on aerial photographs taken over the past 20 years, field surveys on geology, field measurement of channel cross-sections, laboratory assessment of slope material properties, and slope stability analysis. Such a combined analysis yields a more robust understanding of the triggering mechanism of landslides and debris flows

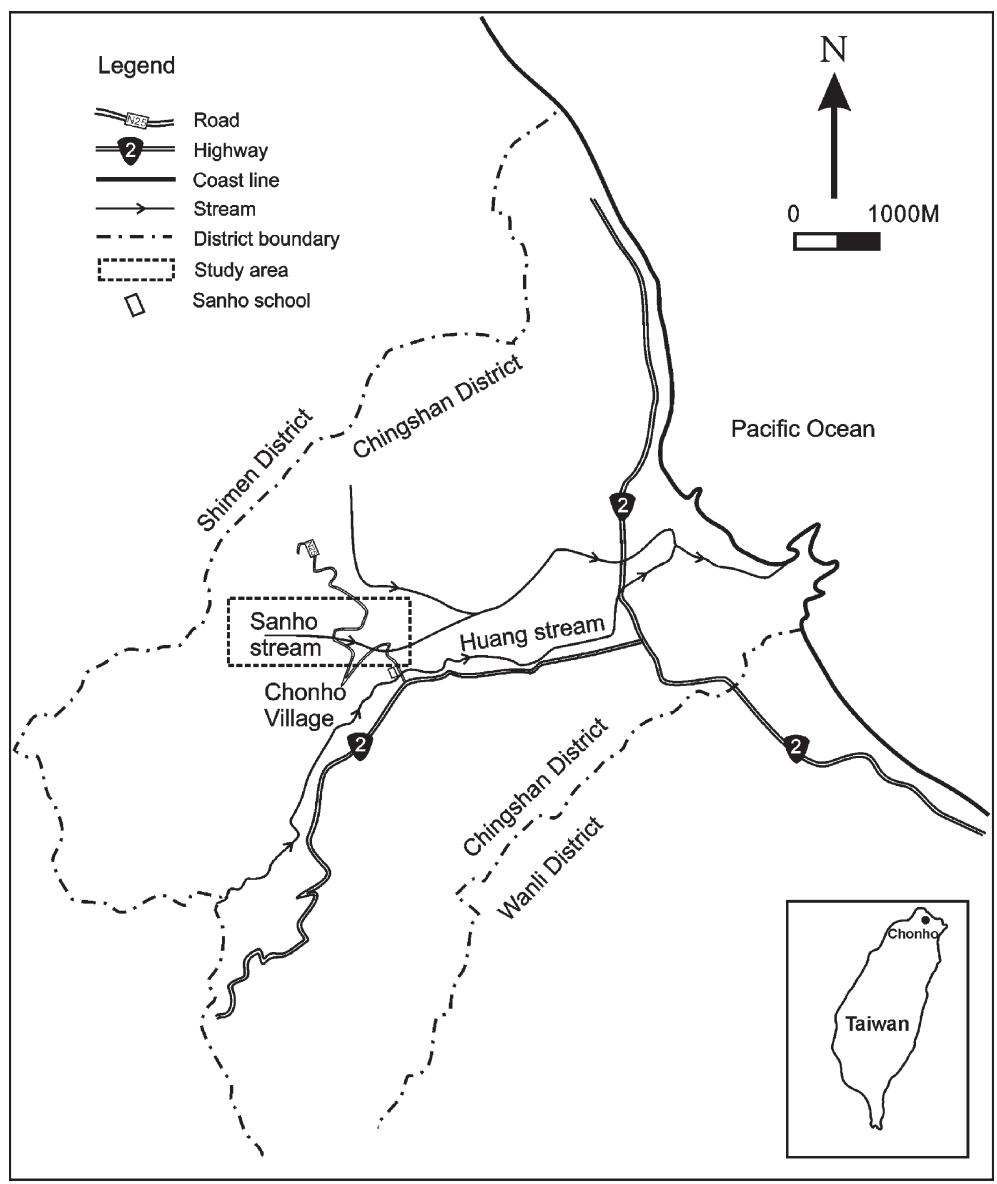

Fig. 1. Location of the study area. 
than any single approach (Hansen, 1984; Petley et al., 2002).

\section{Study area}

The Chonho area has a subtropical climate with average annual precipitation of ca. $4000 \mathrm{~mm}$. On average, rainfall occurs on 190 days per year, and approximately four typhoons hit the area per year. Most typhoons occur during the period between July and October. The heaviest rainfall typically occurs in September and October, with a monthly average of $720 \mathrm{~mm}$. For most of the summer, the weather is dry and the temperature ranges from 23 to $30{ }^{\circ} \mathrm{C}$. In winter, the northeasterly monsoons bring in frontal depressions with intermittent rainfall and temperatures ranging between 8 and $16{ }^{\circ} \mathrm{C}$. In December and January, the monthly rainfall is about $365 \mathrm{~mm}$. The precipitation in the study area comes mostly from typhoons in early autumn and northeasterly monsoons in winter.

The catchment studied has a drainage area of about $1.4 \mathrm{~km}^{2}$. Its typical hillslope gradients are between $20^{\circ}$ and $45^{\circ}$. Chonho Village is located at an elevation of $50 \mathrm{~m}$ a.s.l. and on an alluvial deposit which covers an area of $0.3 \mathrm{~km}^{2}$. The surface gradient of the alluvial deposit ranges from $2^{\circ}$ to $8^{\circ}$. The Sanho stream above Chonho Village has an average gradient of $12^{\circ}$.

The headwaters of the study area are located in warm temperate rain forest. The upper $60 \%$ of the catchment is covered with lauraceae forest composed of incense machilus, camphor trees and large-leaved machilus. Approximately $25 \%$ of the catchment with elevations between 110 and $180 \mathrm{~m}$ is covered by bamboo and bluestem. The downstream reaches below $110 \mathrm{~m}$ in elevation are located in farmland. The narrow zone along the main channel consists of bare rock slopes.

The northern and western parts of the study area are underlain by the Tatun volcanic series composed of lava flow, volcanic ash and pyroclastic bedrock (Fig. 2), which are thought to have erupted from Tatun volcano at 2.5-2.8 Myr BP (Chen and $\mathrm{Wu}, 1971$ ). The Tatun volcanic series has been divided into fifteen lava flow units and two tuffaceous conglomerate units (Ho, 1986). The tuffaceous conglomerate consists of andesite

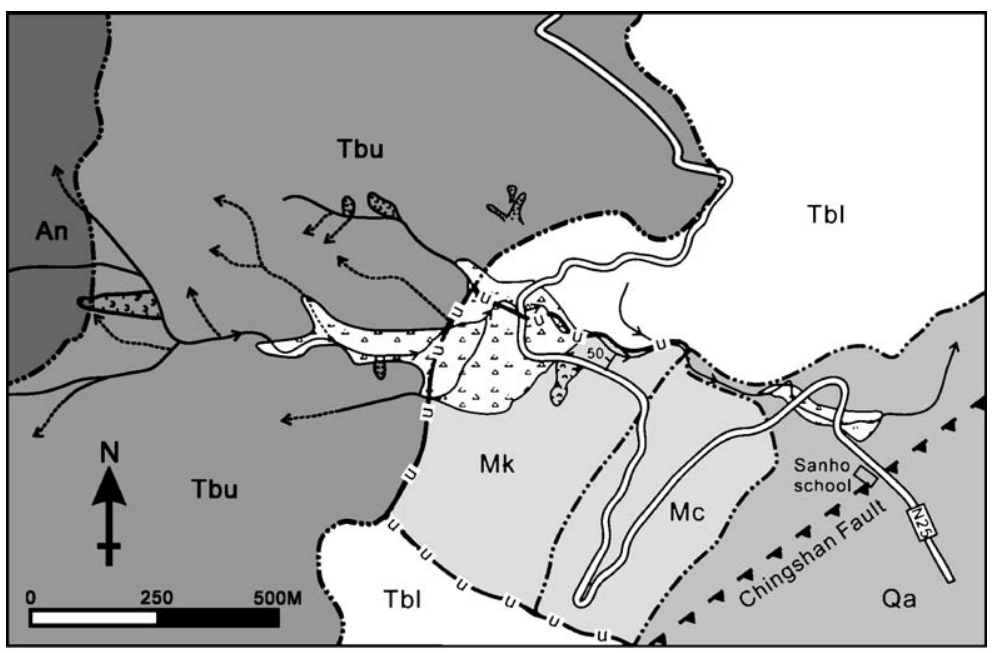

Legend

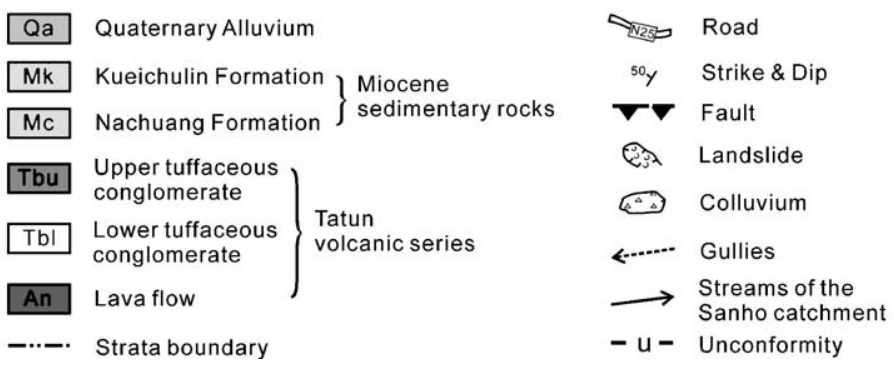

Fig. 2. Environmental geology map showing rock formations in the study area. 
fragments with unconsolidated matrices. This weakly massive and intact conglomerate was subjected to loose cementation. This volcanic material unconformably overlies Miocene sedimentary rocks.

The Sanho stream of the study area drains a region with about $2 \mathrm{~m}$ sediment yields and has a braided pattern along its downstream half. The upper catchment of the stream contains the contact between the lava flow and tuffaceous conglomerate (Fig. 2), and the largest landslide due to Typhoon Xangsane in November 2000 is located on this contact (Fig. 3). About 50\% of bedrock outcrops in the catchment are located along the sidewalls of the stream; the remainders of the outcrops are associated with landslides and gullies on hillslopes.

Another bedrock unconformity appears in the middle of the study area where the tuffaceous conglomerate is in contact with the muddy sandstone of the Miocene Kueichulin Formation (Fig. 2). Most of the debris transported by the Sanho stream has been supplied from the upper part of the study area.

Typhoon Xangsane passed through Taiwan from the southeast to the northwest between October 30 and November 1, 2000. This typhoon caused two periods of intense precipitation in the study area: (1) $90 \mathrm{~mm}$ of rainfall between $5 \mathrm{AM}$ on October 30 and $3 \mathrm{AM}$ on October 31, and (2) $685 \mathrm{~mm}$ of rainfall between $11 \mathrm{AM}$ on October 31 and 2 AM on November 2 (Fig. 4). The debris flow occurred late in the night of November 1 . The length of the debris flow is $1.75 \mathrm{~km}$; its initiation point (Fig. 3A) is located on a hillslope at an elevation of $425 \mathrm{~m}$, where the ground slope is approximately $45^{\circ}$.

\section{Recent change in watershed geomorphology}

In this work, panchromatic black-and-white aerial photographs taken in 1979, 1986, 1994 and 2001 were

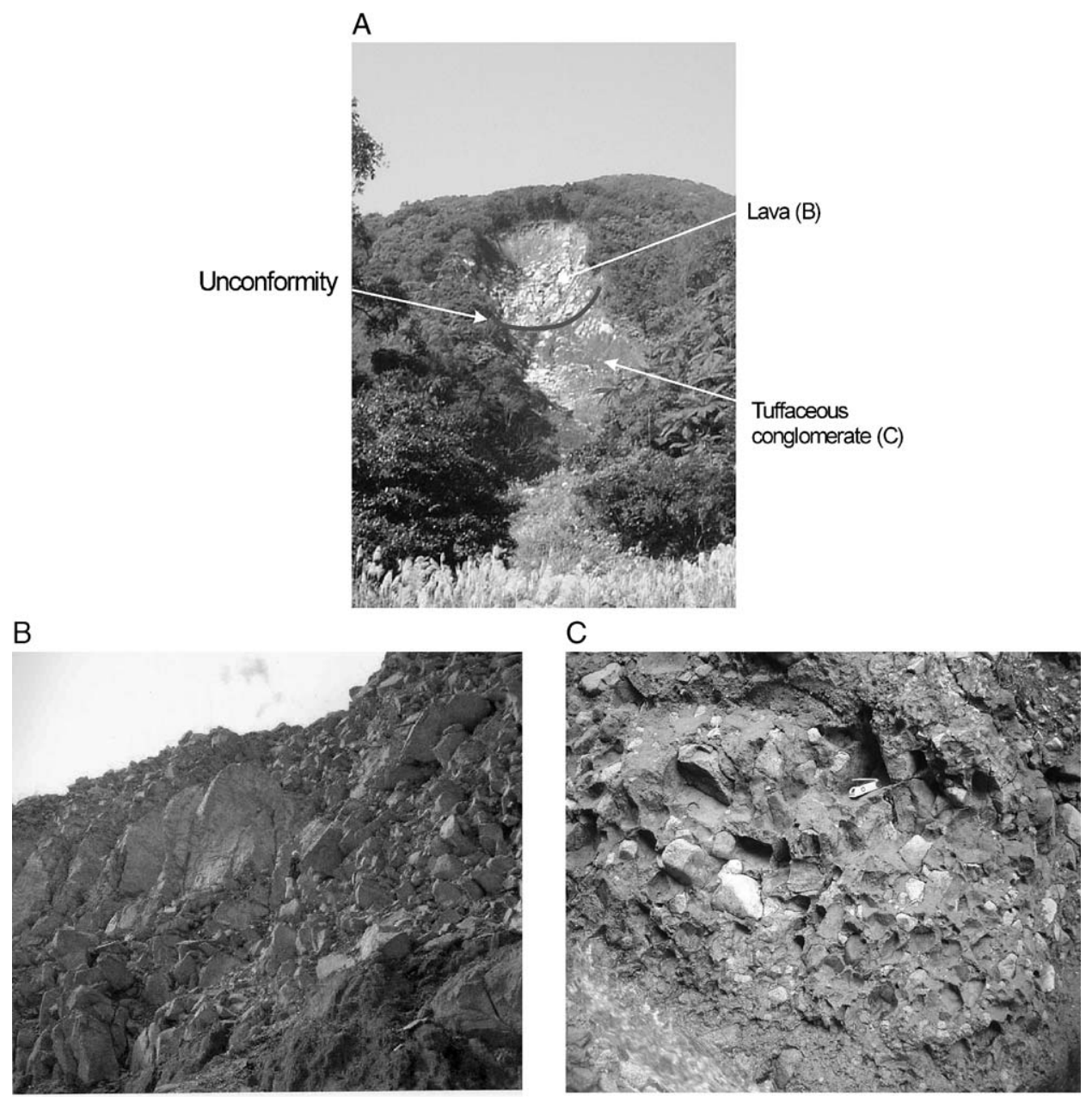

Fig. 3. Photographs of the debris flow source area. (A) Overview. (B) Lava on the upper slope. (C) Tuffaceous conglomerate on the lower slope. 


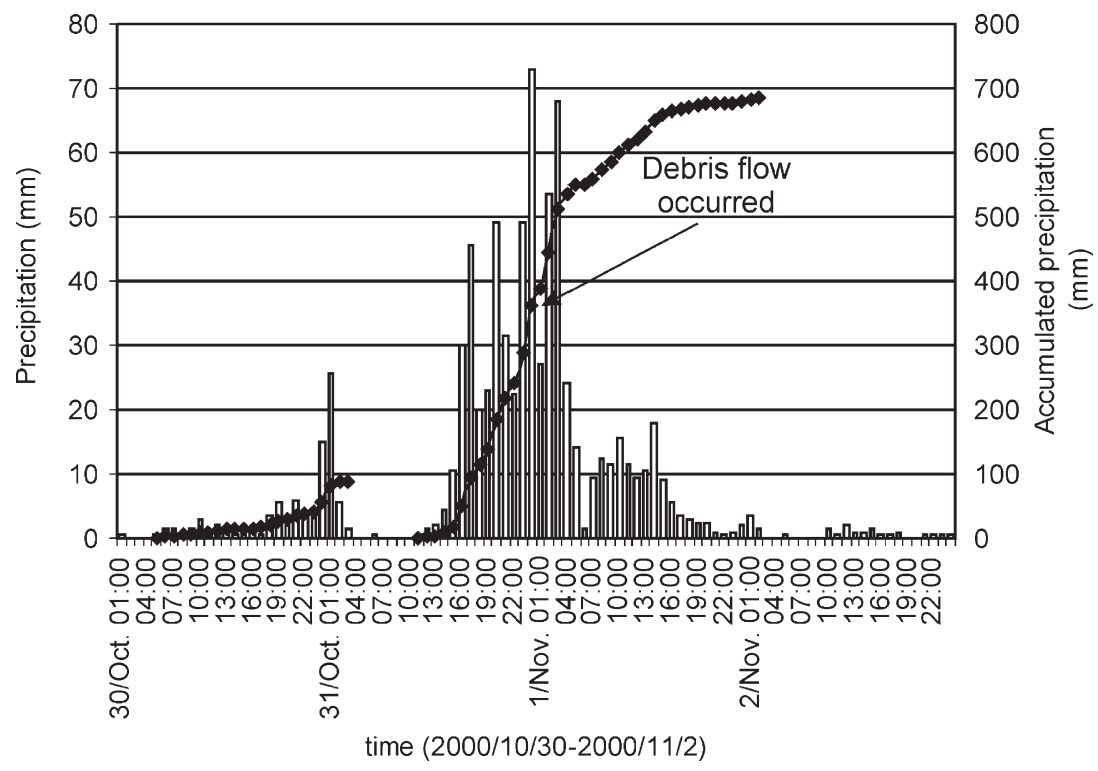

Fig. 4. Distribution of hourly and accumulated precipitation between Oct. 30 and Nov. 2, 2000. The debris flow in the Chonho area occurred after a severe rainstorm of $370 \mathrm{~mm}$.

used to observe topographical changes in the stream beds and mountain slopes over a twenty-year period before and after the debris flow occurred. The scale of the photographs is $1: 17,000$.

In 1979, sixteen landslides were visible in the photograph, only three of which (L06, L10 and L13; $\mathrm{L}$ stands for landslide) were near the main stream (Fig. 5A). These landslides do not appear to be fresh and their material appears to have remained on hillslopes and did not flow into the main stream or major tributaries. The main stream looks narrow and appeared to contain only a little debris. The drainage system appeared to be stable as a whole.

The aerial photographs indicate little topographic change between 1979 and 1994. Some old landslides (L03, L04, L05, L10 and L16) were not visible any more as a result of plant recovery (Fig. 5B). Sediment along the main channel and tributaries was not abundant.

The aerial photograph taken after the passage of Typhoon Xangsane shows 11 new landslides (L17 to L27) including the large landslide in the upper part of the main stream (L22), which was the initial source of the debris flow (Fig. 6A). The run-out deposit of the landslide was about $120 \mathrm{~m}$ long and $20 \mathrm{~m}$ wide.

The majority of the new landslides were located at channel heads. Some of the new landslides (L23, L26 and L27) formed on the sidewalls of the main stream and some of the resultant debris entered the stream. The debris was partly removed by surface water during the typhoon. Some northern tributaries also transported large amounts of debris supplied from the new or reactivated landslides (L09, L15, L24 and L25).

The sidewalls of the trunk stream without landslides were also eroded to some extent as a result of typhooninduced flooding. The number of non-vegetated gullies increased and some gullies were extended. Some farmlands were covered with debris and some paved roads were destroyed.

In summary, the study area during the few decades before Typhoon Xangsane on November 1, 2000 was characterized by very limited geomorphological changes. However, Typhoon Xangsane suddenly triggered rapid erosion with landslides and gullying, yielding a large amount of sediment.

\section{Field surveys of geology and topographic change}

Detailed field observations of geology and geomorphology in relation to the November 2000 landslides and debris flow were performed. Fig. 6B shows geomorphological characteristics of the study area soon after the hazard. Symbols G and A stand for gullies and artificial features such as constructions, public roads and farmland.

The area affected by the landslides and debris flow can be divided into three sub-areas (Fig. 7A). In the source area, landslides resulted in a series of scars. In the flow area, material from channel sidewalls had first slid into the valley bottom, creating many small lateral lobes, 
A

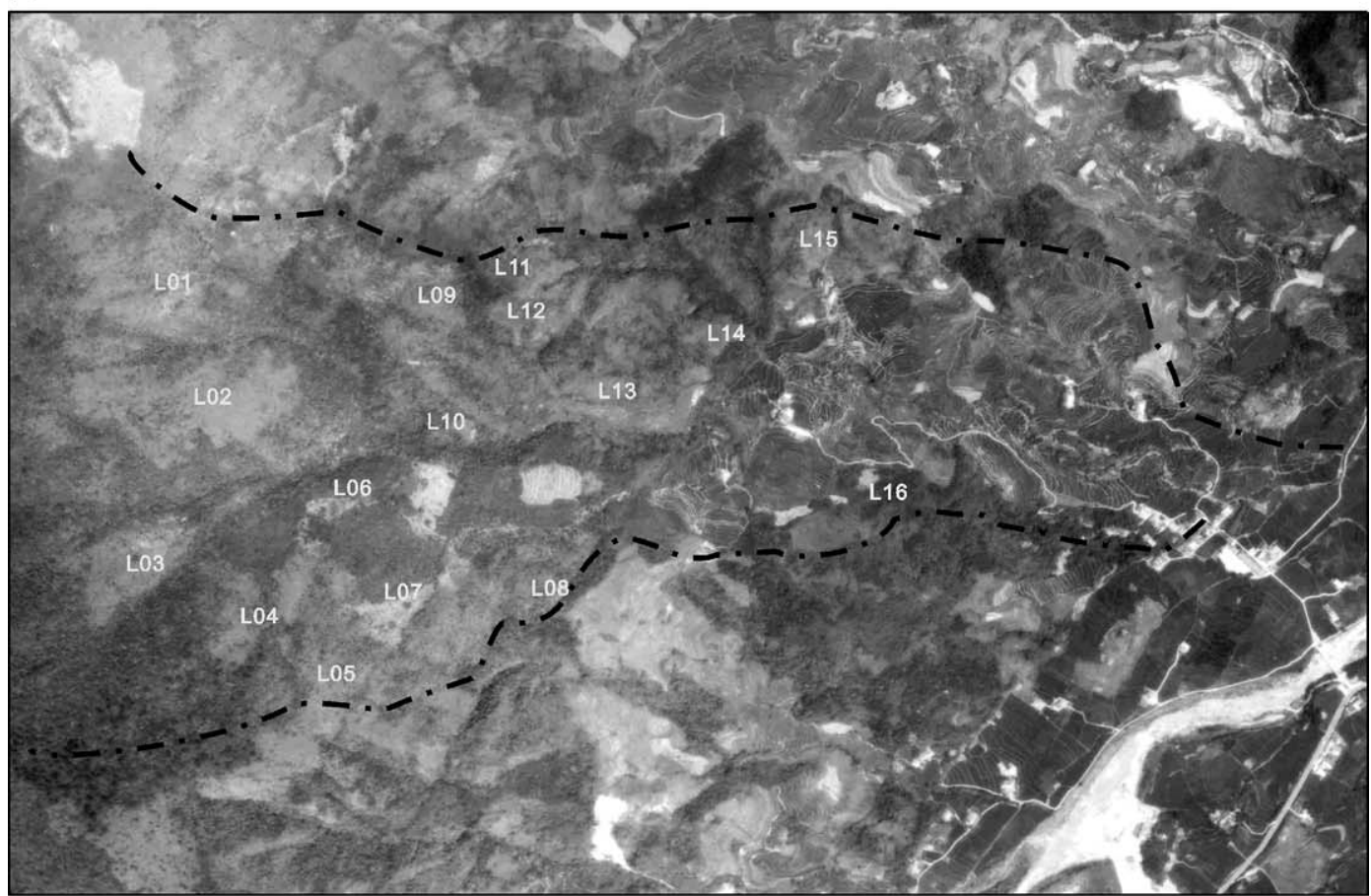

B

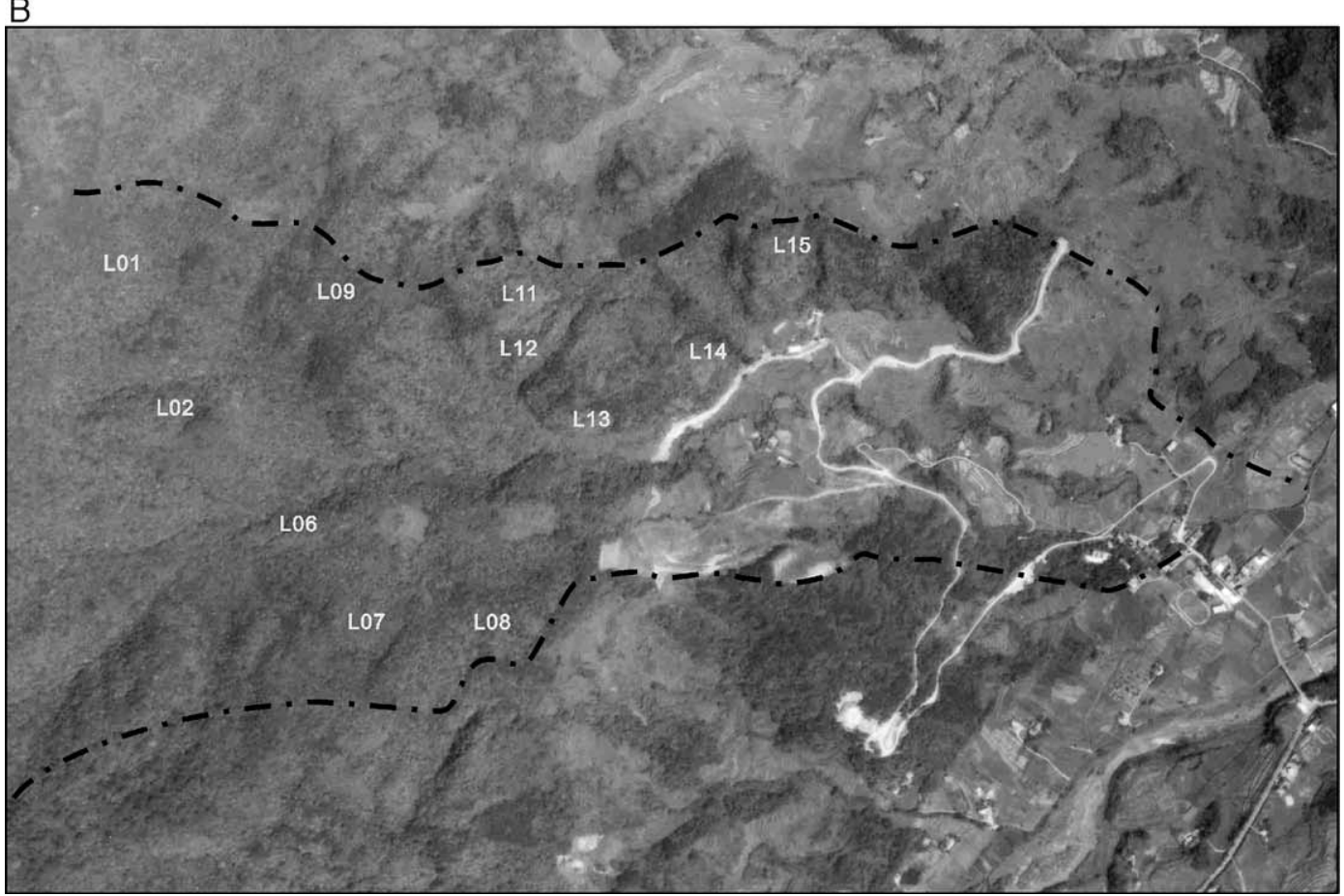

Fig. 5. (A) Aerial photograph of the study area taken in 1979. Most old landslides are away from streams. (B) Aerial photograph taken in 1994 showing few topographic changes from 1979.

and they were subsequently removed by the debris flow. The depositional area was located downstream, along the north part of the Sanho school. In the following three subsections, geomorphological and geological descriptions of the three areas will be given based on the results of our field surveys. 


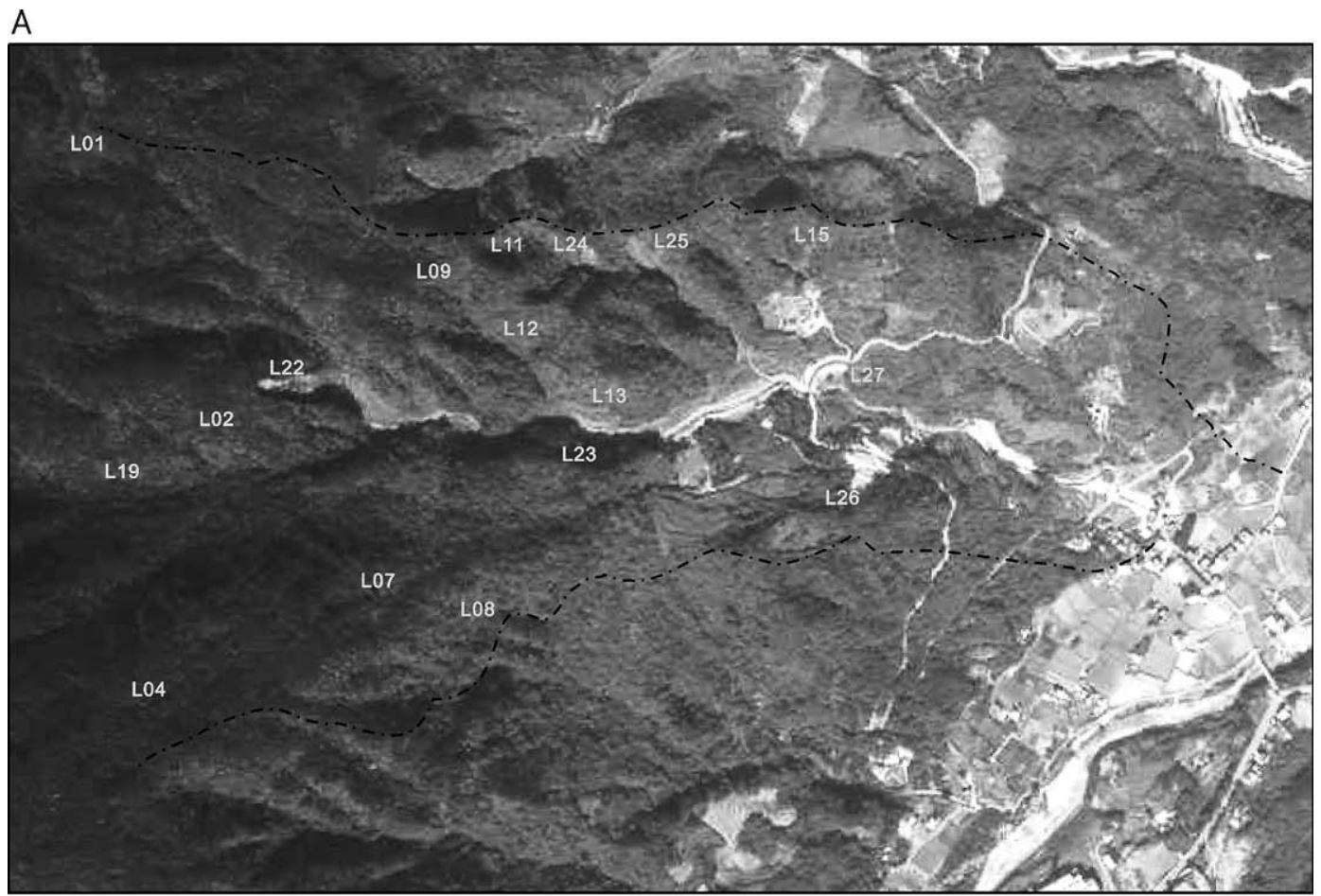

B

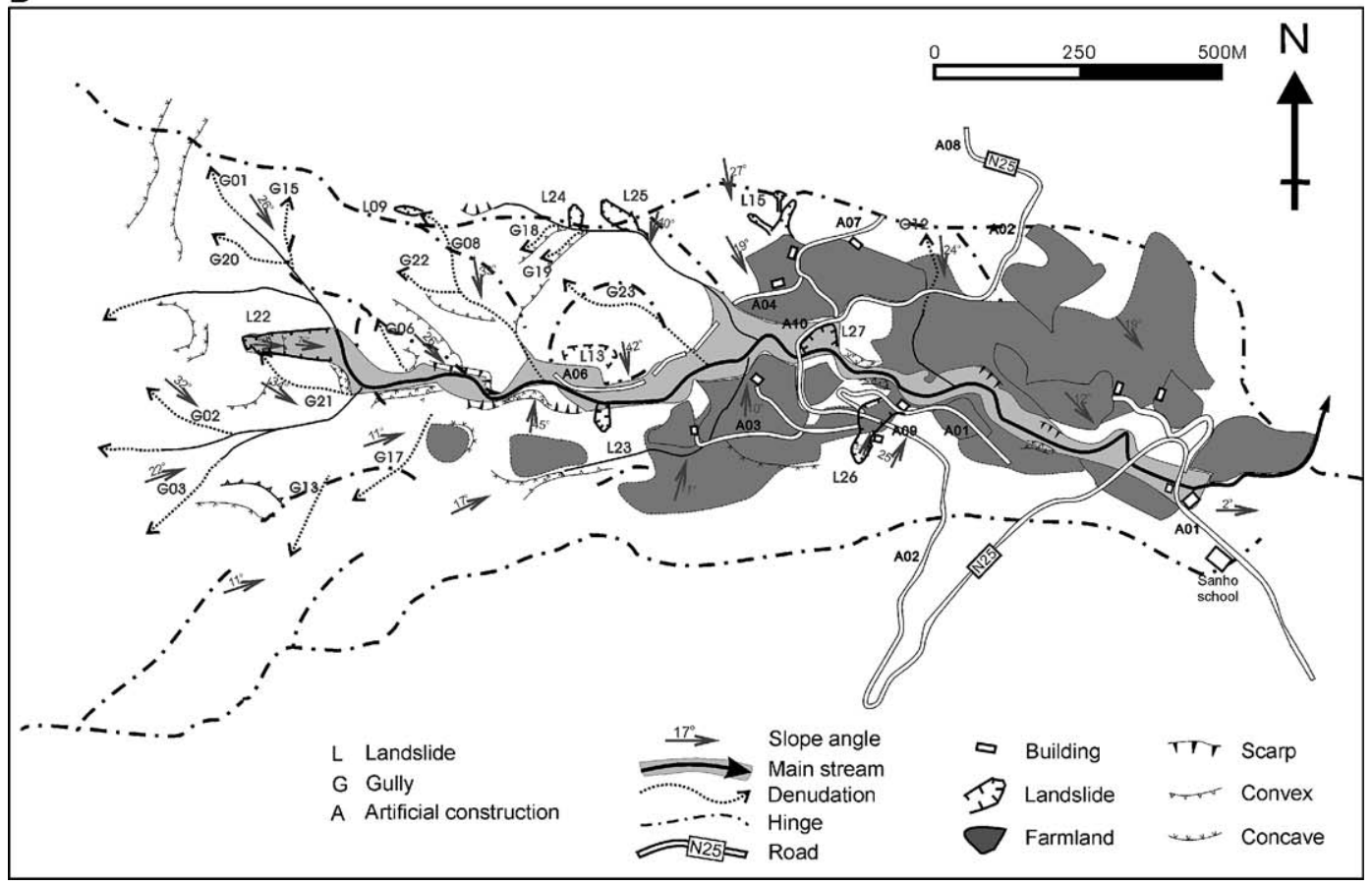

Fig. 6. (A) Aerial photograph taken in 2001 showing devastation caused by Typhoon Xangsane. A large landslide appeared in the upper part of the main stream (L22). (B) Geomorphological map of the study area based on the aerial photograph of (A) and field surveys along the stream banks and trails. 

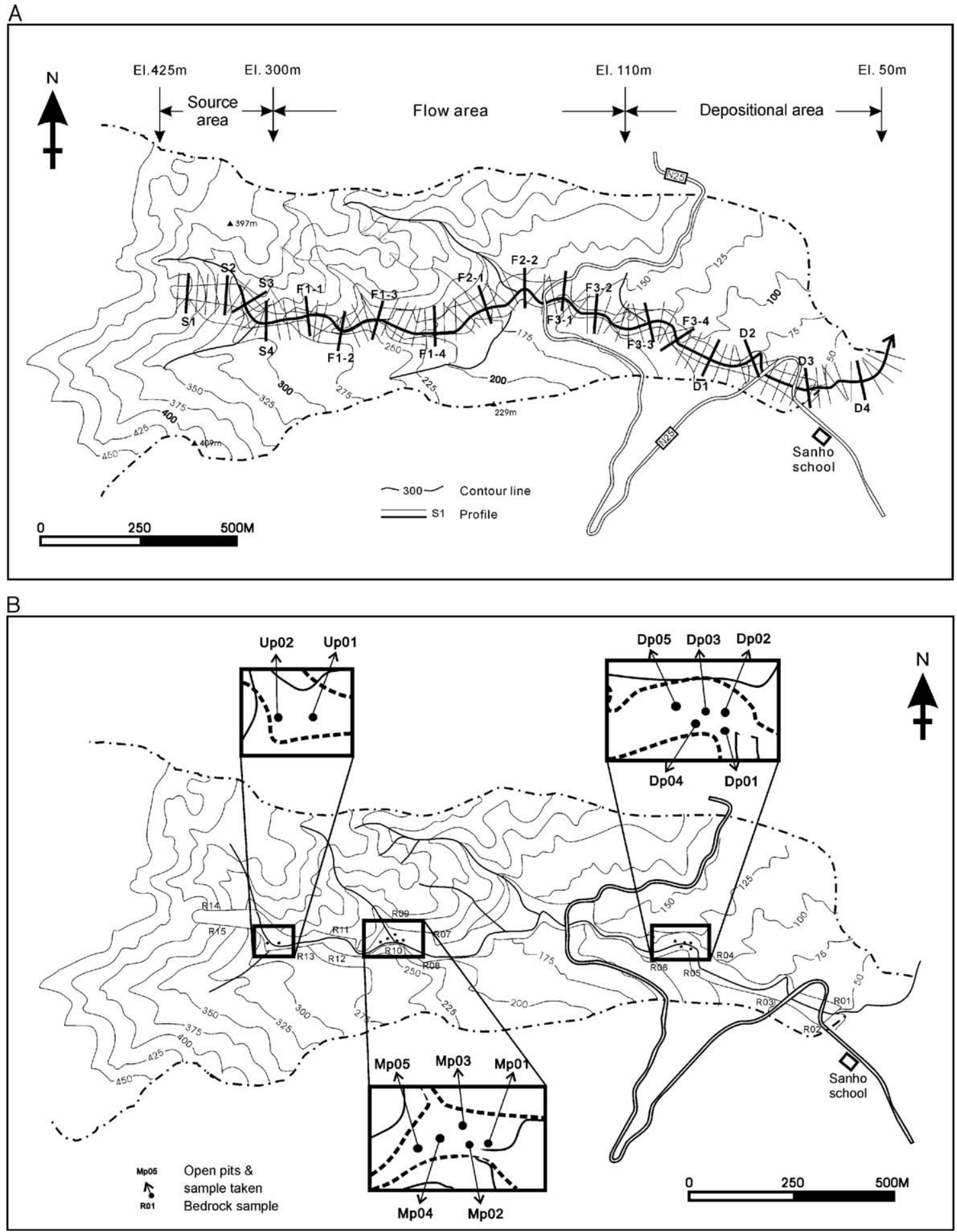

Fig. 7. (A) Location of 71 cross-sections perpendicular to the stream with a $25-\mathrm{m}$ interval. The sections were used to calculate the volume of erosion and deposition due mainly to the debris flow. (B) Locations of open pits and bedrocks where samples for laboratory tests were taken. 


\subsection{Source area}

The source area of the debris flow ranges from 300 to $425 \mathrm{~m}$ in elevation and is about $200 \mathrm{~m}$ in length. The scar of the landslide that caused the debris flow is a spoon-shaped depression (Fig. 3A), on which almost no debris has remained. The landslide was around $10 \mathrm{~m}$ deep, $30 \mathrm{~m}$ wide and $95 \mathrm{~m}$ long. The angle of the landslide gradually shifts from $40^{\circ}$ at the top to $20^{\circ}$ at the bottom.

As noted before, the unconformity between the light grey lava (Fig. 3B) and the tuffaceous conglomerate (Fig. 3C) occurs in the landslide scar. The orientation of the unconformity is $\mathrm{N} 70^{\circ} \mathrm{E} / 15^{\circ} \mathrm{S}$. The lava flow displays rhyolitic textures with major joint directions of $\mathrm{N} 6^{\circ} \mathrm{E} /$ $15^{\circ} \mathrm{S}, \mathrm{N} 71^{\circ} \mathrm{E} / 75^{\circ} \mathrm{S}$, and $\mathrm{N} 75^{\circ} \mathrm{E} / 82^{\circ} \mathrm{N}$.

\subsection{Flow area}

The flow area ranges from 110 to $300 \mathrm{~m}$ in elevation and is $1100 \mathrm{~m}$ in length. The upper part of the flow area consists mainly of tuffaceous conglomerate, which is composed mostly of andesite rock fragments and a dark reddish matrix of fine sand, while the lower part below ca. $180 \mathrm{~m}$ a.s.l. consists of muddy sandstone.

Some debris flow material was deposited along the stream. The deposited material is composed of various loose rock fragments, sand, and mud. The observed andesite fragments range from 10 to $30 \mathrm{~cm}$ in diameter and are round to subangular in shape.

\subsection{Depositional area}

The depositional area ranges from 50 to $110 \mathrm{~m}$ in elevation and $450 \mathrm{~m}$ in length. The orientation of partly exposed bedrocks bedding ranges from $\mathrm{N} 35^{\circ}$ to $\mathrm{N} 50^{\circ}$ and it dips $52^{\circ}$ towards the north. Two sets of observed joints are $\mathrm{N} 85^{\circ} \mathrm{E} / 60^{\circ} \mathrm{S}$ and $\mathrm{N} 10^{\circ} \mathrm{E} / 63^{\circ} \mathrm{N}$, providing the potential geometry of wedge and plane failure models (Hoek and Brown, 1997). Most of the deposited debris flow materials are andesite boulders and tuffaceous debris. The boulders are subround to round in shape, and the debris is subangular to subround in shape.

\subsection{Cross-section surveys}

River cross-sections were surveyed after the debris flow in 2001, and they were compared with those surveyed in 1994, using topographic maps compiled by the Taiwan Agricultural and Forestry Aerial Survey Bureau (TAFASB) with a contour interval of $5 \mathrm{~m}$. We
Table 1

Volume of erosion and deposition in different sections of the study area

\begin{tabular}{lrlcr}
\hline & $\begin{array}{l}\text { Source } \\
\text { area }\end{array}$ & $\begin{array}{l}\text { Flow } \\
\text { area }\end{array}$ & $\begin{array}{l}\text { Depositional } \\
\text { area }\end{array}$ & Total \\
\hline Erosion $\left(\mathrm{m}^{3}\right)$ & 68,890 & 53,410 & 420 & 122,720 \\
Deposition $\left(\mathrm{m}^{3}\right)$ & 750 & 67,900 & 37,320 & 105,970 \\
$\begin{array}{l}\text { Deposition-Erosion } \\
\left(\mathrm{m}^{3}\right)\end{array}$ & $-68,140$ & 14,490 & 36,900 & $-16,750$ \\
\hline
\end{tabular}

selected the maps of 1994 to represent the situation soon before the debris flow, because the TAFASB and local experts advised that there had been little topographic change in the study area between 1994 and 2000. In each survey, 71 cross-sections perpendicular to the channel were measured with a $25-\mathrm{m}$ interval, from the source area at $450 \mathrm{~m}$ in elevation to the deposition area at $50 \mathrm{~m}$ in elevation (Fig. 7A). The total volume of deposition between 1994 and 2001 was $105,970 \mathrm{~m}^{3}$ and that of erosion was $122,720 \mathrm{~m}^{3}$, showing that in total nearly $16,750 \mathrm{~m}^{3}$ of sediment had left the stream (Table 1). However, not only the depositional area but also the flow area was characterized by net deposition.

\section{Geotechnical investigation}

Geotechnical data about the debris flow and the source area were also collected in the field. The distribution of bedrock discontinuities (e.g., joints and bedding planes) was investigated in details, and then the physical properties of the bedrock material were analyzed in the laboratory.

\subsection{Physical properties of sediment}

Sediment samples for particle size analysis were taken from twelve open pits in the source, flow and depositional areas of the debris flow (Fig. 7B). Two pits were dug in the source area, five pits in the flow area, and five pits in the depositional area. Each pit was a cube with a side length of $1 \mathrm{~m}$. Most of the observed soil type was GP (poorly graded gravel) according to the Unified Soil Classification System.

The majority of material deposited in the source and flow areas was non-plastic silty gravel, whereas plastic silt formed the major component of sediment in the depositional area (Fig. 8). Overall, the fine silt and clay fractions of the deposits comprise less than $10 \%$ of the sample, and the plasticity index ranges from 2.28 to 8.40 (Table 2). More than $80 \%$ of sediment particles have diameters larger than $2 \mathrm{~mm}$. 


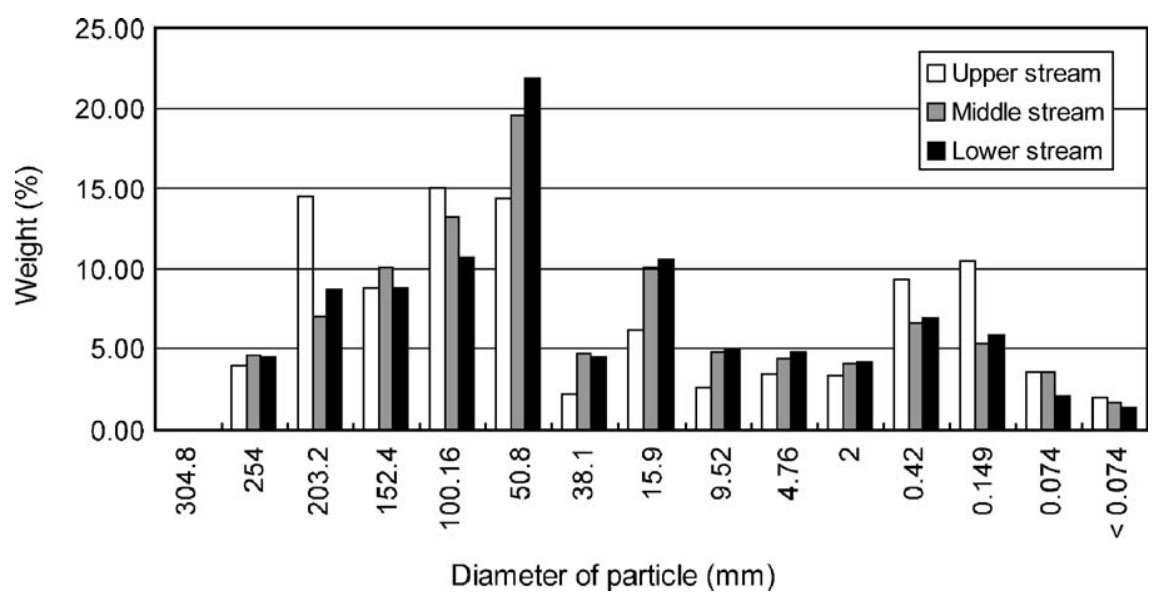

Fig. 8. Particle size distributions of river sediment from different locations.

\subsection{Physical properties of bedrock}

Bedrock samples were collected from fifteen outcrops along the stream sidewalls and tests were undertaken to determine the physical properties and shear strength using the methods of the International Society of Rock Mechanics (Brown, 1981). The rock samples R01 to R06 are sandstones; R07 to R13 are tuffaceous conglomerates; R14 to R15 are lavas. Table 3 shows that the saturation of tuffaceous conglomerate exceeds $40 \%$, and its porosity is less than $10 \%$.

Experimental results also show that the friction angle of the muddy sandstone ranges from $30^{\circ}$ to $36^{\circ}$ in dry conditions (Table 3). The samples of tuffaceous conglomerate have friction angles ranging from $32^{\circ}$ to $39^{\circ}$ in dry conditions and $28^{\circ}$ to $33^{\circ}$ in saturated conditions. Friction angles for the lava samples range from $34^{\circ}$ to $49^{\circ}$ in dry conditions and $23^{\circ}$ to $38^{\circ}$ when saturated.

\subsection{Bedrock discontinuity analysis}

Bedrock discontinuity analysis was undertaken for some rock slopes on both sides of the trunk stream based on a semi-quantitative set of parameters (Selby, 1987; Priest, 1992). The geological orientations of bedding, joints and diverse slope surfaces were measured at 15 locations (Ocp01-Ocp15) where the rock samples were collected, and were plotted on a stereonet to assess the likelihood of slope failure. The

Table 2

Physical properties of river sediment

\begin{tabular}{|c|c|c|c|c|c|c|c|c|c|c|c|c|c|c|c|}
\hline Pit no & $\begin{array}{l}\text { \#10 passing } \\
(\%)\end{array}$ & $\begin{array}{l}\# 200 \\
\text { passing } \\
(\%)\end{array}$ & $\begin{array}{l}D_{50} \\
(\mathrm{~mm})\end{array}$ & $\begin{array}{l}C_{\mathrm{u}} \\
(\mathrm{mm})\end{array}$ & $\begin{array}{l}W_{\mathrm{n}} \\
(\%)\end{array}$ & $\begin{array}{l}\gamma_{\text {int }} \\
\left(\mathrm{t} / \mathrm{m}^{3}\right)\end{array}$ & $\begin{array}{l}\gamma_{\text {sat }} \\
\left(\mathrm{t} / \mathrm{m}^{3}\right)\end{array}$ & $e$ & $\begin{array}{l}n \\
(\%)\end{array}$ & $\begin{array}{l}\text { Sat } \\
(\%)\end{array}$ & $\begin{array}{l}\text { LL } \\
(\%)\end{array}$ & $\begin{array}{l}\text { PL } \\
(\%)\end{array}$ & PI & $\mathrm{Cf}$ & Remarks \\
\hline Up01 & 27.54 & 2.32 & 55 & 450 & 22.45 & 1.44 & 1.62 & 0.78 & 43.91 & 77.87 & - & - & $\mathrm{NP}$ & GP & \multirow[t]{2}{*}{ Source area } \\
\hline Up02 & 23.26 & 1.60 & 90 & 478 & 21.96 & 1.38 & 1.57 & 0.77 & 43.36 & 78.68 & - & - & NP & GP & \\
\hline Mp01 & 20.82 & 2.95 & 43 & 412 & 13.91 & 1.75 & 1.93 & 0.66 & 39.69 & 56.87 & 38.14 & 35.86 & 2.28 & GP & \multirow[t]{5}{*}{ Flow area } \\
\hline Mp02 & 17.87 & 1.32 & 51 & 192 & 17.1 & 1.76 & 1.93 & 0.76 & 43.16 & 59.39 & 40.57 & 35.62 & 4.95 & GP & \\
\hline Mp03 & 19.07 & 1.67 & 83 & 367 & 10.44 & 1.81 & 2.02 & 0.61 & 37.86 & 46.34 & - & - & NP & GP & \\
\hline Mp04 & 13.28 & 1.51 & 60 & 123 & 9.26 & 1.75 & 1.94 & 0.51 & 33.64 & 50.59 & 36.43 & 29.67 & 6.76 & GP & \\
\hline Mp05 & 14.91 & 0.95 & 61 & 126 & 8.74 & 1.85 & 2.03 & 0.48 & 32.47 & 49.56 & - & - & $\mathrm{NP}$ & GP & \\
\hline Dp01 & 17.40 & 1.47 & 38 & 375 & 11.49 & 1.83 & 2.03 & 0.63 & 38.52 & 49.83 & 41.12 & 32.72 & 8.40 & GP & \multirow{5}{*}{$\begin{array}{l}\text { Depositiona } \\
\text { area }\end{array}$} \\
\hline Dp02 & 19.93 & 1.90 & 80 & 440 & 16.55 & 1.75 & 1.92 & 0.71 & 41.57 & 62.20 & 33.88 & 27.12 & 6.76 & GP & \\
\hline Dp03 & 15.60 & 0.76 & 68 & 148 & 18.79 & 1.78 & 1.93 & 0.76 & 43.19 & 67.02 & 37.91 & 32.27 & 5.25 & GP & \\
\hline Dp04 & 11.65 & 1.03 & 58 & 73 & 10.68 & 1.85 & 2.08 & 0.68 & 40.59 & 42.78 & 35.69 & 31.97 & 3.27 & GP & \\
\hline Dp05 & 16.78 & 1.46 & 50 & 115 & 11.5 & 1.87 & 2.10 & 0.73 & 42.36 & 43.16 & 35.46 & 30.15 & 5.31 & GP & \\
\hline
\end{tabular}

$D_{50}$ : soil diameter at $50 \%$ weight is finer, $C_{\mathrm{u}}$ : coefficient of uniformity, $W_{\mathrm{n}}$ : water content, $\gamma_{\mathrm{int}}$ : in situ unit weight, $\gamma_{\text {sat }}$ saturated unit weight, $e$ : void ratio, $n$ : porosity, Sat: degree of saturation, LL: liquid limit, PL: plastic limit, NP: non-plasticity, PI: plasiticity index, Cf: classification of soil type, GP: poorly graded gravel. 
Table 3

Physical properties of rock samples from the study area

\begin{tabular}{|c|c|c|c|c|c|c|c|c|c|c|c|}
\hline \multirow[t]{2}{*}{$\begin{array}{l}\text { Sample } \\
\text { location }\end{array}$} & \multirow[t]{2}{*}{ Rock type } & \multirow[t]{2}{*}{$\begin{array}{l}W_{\mathrm{n}} \\
(\%)\end{array}$} & \multirow[t]{2}{*}{$\begin{array}{l}\gamma_{\text {int }} \\
\left(\mathrm{t} / \mathrm{m}^{3}\right)\end{array}$} & \multirow[t]{2}{*}{$\begin{array}{l}\gamma_{\text {sat }} \\
\left(\mathrm{t} / \mathrm{m}^{3}\right)\end{array}$} & \multirow[t]{2}{*}{$e$} & \multirow[t]{2}{*}{$\begin{array}{l}n \\
(\%)\end{array}$} & \multirow[t]{2}{*}{$\begin{array}{l}\text { Sat } \\
(\%)\end{array}$} & \multicolumn{2}{|c|}{ Dry condition } & \multicolumn{2}{|l|}{$\begin{array}{l}\text { Saturated } \\
\text { condition }\end{array}$} \\
\hline & & & & & & & & $\begin{array}{l}c \\
\left(\mathrm{~kg} / \mathrm{cm}^{2}\right)\end{array}$ & $\begin{array}{l}\phi \\
\left({ }^{\circ}\right)\end{array}$ & $\begin{array}{l}c \\
\left(\mathrm{~kg} / \mathrm{cm}^{2}\right)\end{array}$ & $\begin{array}{l}\phi \\
\left({ }^{\circ}\right)\end{array}$ \\
\hline R01 & Muddy sandstone & 3.86 & 2.33 & 2.47 & 0.16 & 14.11 & 54.80 & 0.1 & 34.2 & - & - \\
\hline $\mathrm{R} 02$ & Muddy sandstone & 4.15 & 2.41 & 2.55 & 0.15 & 13.31 & 65.12 & 0.1 & 34.3 & - & - \\
\hline $\mathrm{R} 03$ & Muddy sandstone & 3.32 & 2.41 & 2.54 & 0.15 & 13.32 & 52.09 & 0.1 & 35.3 & - & - \\
\hline R04 & Muddy sandstone & 12.50 & 1.92 & 2.21 & 0.41 & 29.17 & 57.64 & 0.2 & 30.2 & - & - \\
\hline R05 & Muddy sandstone & 11.79 & 1.95 & 2.32 & 0.57 & 36.44 & 39.82 & 0 & 32.6 & - & - \\
\hline R06 & Muddy sandstone & 5.24 & 2.29 & 2.57 & 0.38 & 27.61 & 31.50 & 0 & 36.4 & - & - \\
\hline R07 & Tuffaceous conglomerate & 1.15 & 2.62 & 2.68 & 0.07 & 6.18 & 45.57 & 0 & 35.5 & 0.2 & 31.5 \\
\hline R08 & Tuffaceous conglomerate & 2.16 & 2.32 & 2.41 & 0.09 & 8.67 & 52.70 & 0.1 & 31.5 & 0.2 & 28.2 \\
\hline R09 & Tuffaceous conglomerate & 2.55 & 2.74 & 2.83 & 0.10 & 9.41 & 67.42 & 0 & 36.5 & 0.5 & 33.0 \\
\hline $\mathrm{R} 10$ & Tuffaceous conglomerate & 1.53 & 2.62 & 2.71 & 0.10 & 9.15 & 39.75 & 0 & 35.0 & 0.5 & 30.5 \\
\hline R11 & Tuffaceous conglomerate & 1.09 & 2.74 & 2.78 & 0.05 & 4.45 & 64.44 & 0.1 & 39.0 & 0.7 & 32.5 \\
\hline $\mathrm{R} 12$ & Tuffaceous conglomerate & 1.10 & 2.73 & 2.78 & 0.05 & 4.75 & 60.18 & 0 & 38.0 & 0.3 & 31.8 \\
\hline R13 & Tuffaceous conglomerate & 2.61 & 2.68 & 2.77 & 0.09 & 8.41 & 76.25 & 0.2 & 38.3 & 0.7 & 31.0 \\
\hline R14 & Lava & 0.36 & 2.74 & 2.78 & 0.04 & 3.94 & 24.39 & 0 & 48.2 & 0.3 & 37.1 \\
\hline R15 & Lava & 0.36 & 2.75 & 2.78 & 0.04 & 3.67 & 26.26 & 0.2 & 37.1 & 0.2 & 32.5 \\
\hline
\end{tabular}

“-” collapse after water emerging, $W_{\mathrm{n}}:$ water content, $\gamma_{\text {int }}:$ in situ unit weight, $\gamma_{\text {sat }}:$ saturated unit weight, $e$ : void ratio, $n$ : porosity, Sat: degree of saturation.

rock types on sites Ocp01-Ocp06 are mainly composed of muddy sandstone, while those on Ocp07-Ocp13 consist of tuffaceous conglomerate, and Ocp14 and Ocp 15 compose of the lava flow. These three groups also correspond to the depositional, flow and source areas, respectively.

The orientation of the bedding plane and the dip angle were measured at each outcrop. The constructed stereonets (Fig. 9) indicate that Ocp01, Ocp11 and Ocp13 have a potential of plane failure; Ocp01 and Ocp15 have a possibility of wedge failure; and Ocp02, Ocp04 and Ocp09 have a potential of topple failure.

\subsection{Safety factor analysis}

The safety factor represents the average ability of a slope profile to resist gravitational forces and other external forces. The safety factors for the three types of failure (Hoek and Bray, 1981) were computed for the bedrock outcrops along the stream.

For plane slope failure:

$F=\frac{c \times l+\left(W \cos \psi_{\rho}-U-V \sin \psi_{\rho}\right) \times \tan \phi_{\rho}}{W \sin \psi_{\rho}+V \cos \psi_{\rho}}$

where $F$ is the safety factor, $c$ is the cohesion $\left(\mathrm{kN} / \mathrm{m}^{2}\right)$, $\psi_{\rho}$ is the failure angle (degrees), $l$ is the length of the slip surface $(\mathrm{m}), W$ is the weight of the failure mass $(\mathrm{kN} / \mathrm{m})$,
$U$ is the uplift force $(\mathrm{kN} / \mathrm{m}), V$ is the lateral water pressure $(\mathrm{kN} / \mathrm{m})$, and $\phi$ is the friction angle (degrees).

For wedge slope failure:

$F=\frac{\left(R_{a}+R_{b}\right) \tan \phi}{W \sin \varphi_{\mathrm{i}}}=\frac{\sin \beta \times \tan \phi}{\sin \frac{1}{2} \xi \times \tan \varphi_{\mathrm{i}}}$

where $R_{a}$ and $R_{b}$ are the normal stress on the two masses $a$ and $b(\mathrm{kN} / \mathrm{m})$ which correspond to two planar discontinuities in the wedge failure, $\xi$ is the intersection angle between the masses $a$ and $b$ (degrees), $\varphi_{1}$ is the dip angle of the line of intersection between the two discontinuities (degrees), and $\beta$ is the tilt angle of the wedge (degrees).

For topple slope failure:

$F=\frac{\tan \phi}{\tan [\alpha-(90-\delta)]}$

where $\alpha$ is the dip angle of the slope surface (degrees), and $\delta$ is the dip angle of the bedrock discontinuity (degrees).

Stability analysis using the plane failure model under normal dry conditions at Ocp01, Ocp11 and Ocp13 reveals a safety factor of $1.07,1.20$, and 1.16 , respectively, indicating high stability. When these slopes are saturated, however, the safety factor falls below 1.0, which indicates that the slopes will fail (Table 4). The application of the wedge failure model to Ocp01 and Ocp15 yields safety factors of 1.06 and 1.41 under 


\section{Outcrop Ocp01}

dry condition

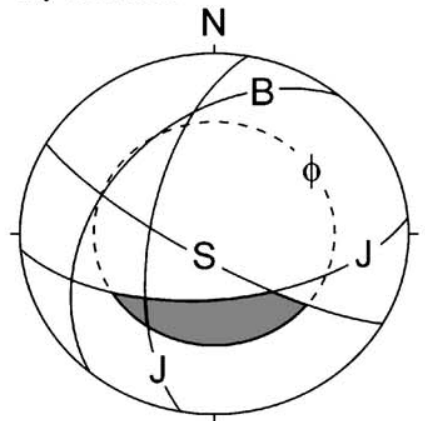

\section{Outcrop Ocp04}

dry condition

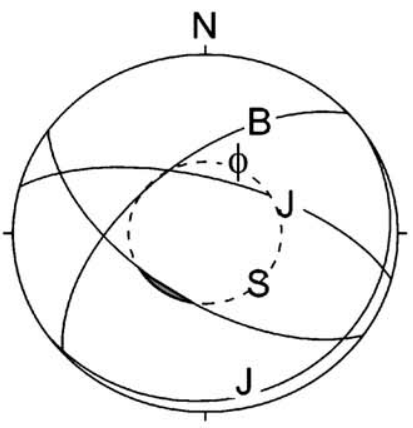

\section{Outcrop Ocp15}

dry condition

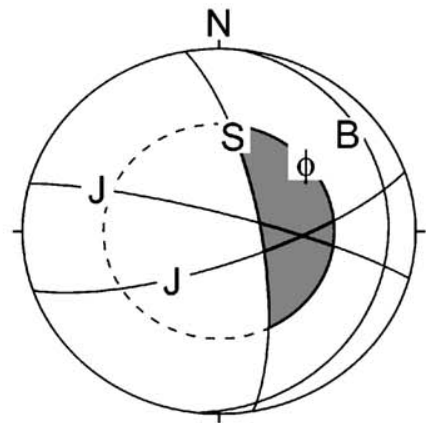

Legend $\quad S$ slope surface
$\phi$ friction angle

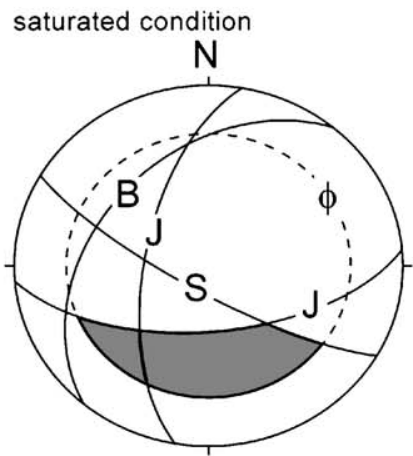

saturated condition

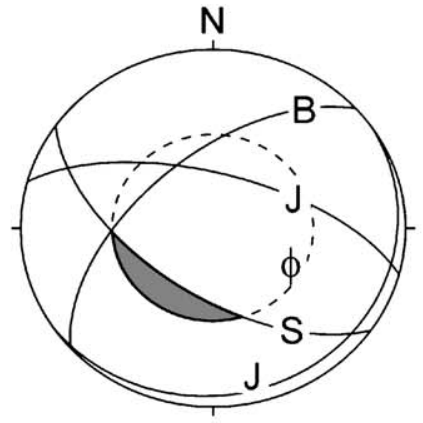

saturated condition

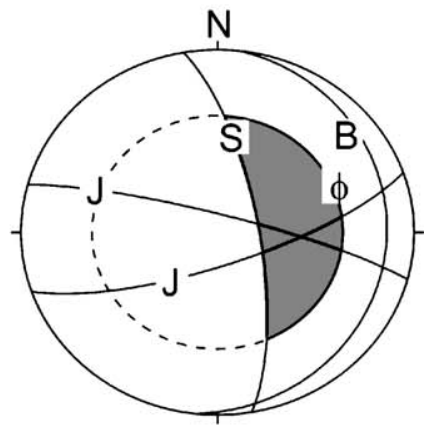

$B$ Bedding $J$ joint

O Potential unstable zone

Fig. 9. Examples of stereonet analysis showing three types of potential unstable zones, illustrated by Ocp01, Ocp04 and Ocp 15 in dry and saturated conditions.

normal dry conditions, but the factor falls to 0.74 and 0.89 under saturated conditions. The application of the topple failure model to Ocp02, Ocp04 and Ocp09 yields safety factors of 1.09, 1.10 and 1.07 under normal dry conditions. When these slopes are saturated, the safety factor falls below 1.0. For the other cases, slopes were found to be stable even under saturated conditions.

\section{Discussion}

Our investigation indicates that the landslides and debris flow due to Typhoon Xangsane occurred during rainfall not only of high intensity (up to $70 \mathrm{~mm} / \mathrm{h}$ ) but also with an exceptionally long period of over $10 \mathrm{~h}$ (Fig. 4). Prolonged rainfall caused a saturated zone to 
Table 4

Examples of safety factor analysis for slopes in the study area

\begin{tabular}{|c|c|c|c|c|c|c|c|}
\hline Slope & $\gamma_{t}\left(t / m^{3}\right)$ & $c\left(\mathrm{~kg} / \mathrm{cm}^{2}\right)$ & $\phi\left({ }^{\circ}\right)$ & Geometric model & Safety factor & Condition & Remark \\
\hline Ocp01 (1) & 2.42 & 0.1 & 34.2 & Plane & $\begin{array}{l}1.07 \\
0.96\end{array}$ & $\begin{array}{l}\text { Dry } \\
\text { Saturated }\end{array}$ & $\begin{array}{l}\text { Critical stable } \\
\text { Fail }\left(3.3 \mathrm{~m}^{\mathrm{a}}\right)\end{array}$ \\
\hline Ocp01 (2) & 2.42 & 0.1 & 34.2 & Wedge & $\begin{array}{l}1.06 \\
0.74\end{array}$ & $\begin{array}{l}\text { Dry } \\
\text { Saturated }\end{array}$ & $\begin{array}{l}\text { Critical stable } \\
\text { Fail }\left(3.1 \mathrm{~m}^{\mathrm{a}}\right)\end{array}$ \\
\hline Ocp02 & 2.51 & 0.1 & 34.3 & Topple & $\begin{array}{l}1.17 \\
0.98\end{array}$ & $\begin{array}{l}\text { Dry } \\
\text { Saturated }\end{array}$ & $\begin{array}{l}\text { Stable } \\
\text { Fail }\left(3.1 \mathrm{~m}^{\mathrm{a}}\right)\end{array}$ \\
\hline Ocp04 & 2.16 & 0.2 & 30.2 & Topple & $\begin{array}{l}1.10 \\
0.94\end{array}$ & $\begin{array}{l}\text { Dry } \\
\text { Saturated }\end{array}$ & $\begin{array}{l}\text { Stable } \\
\text { Fail }\left(2.5 \mathrm{~m}^{\mathrm{a}}\right)\end{array}$ \\
\hline Ocp09 & 2.81 & 0 & 36.5 & Topple & $\begin{array}{l}1.19 \\
0.98\end{array}$ & $\begin{array}{l}\text { Dry } \\
\text { Saturated }\end{array}$ & $\begin{array}{l}\text { Stable } \\
\text { Fail }\left(2.5 \mathrm{~m}^{\mathrm{a}}\right)\end{array}$ \\
\hline Ocp11 & 2.77 & 0.1 & 39.0 & Plane & $\begin{array}{l}1.20 \\
0.95\end{array}$ & $\begin{array}{l}\text { Dry } \\
\text { Saturated }\end{array}$ & $\begin{array}{l}\text { Stable } \\
\text { Fail }\left(2.8 \mathrm{~m}^{\mathrm{a}}\right)\end{array}$ \\
\hline Ocp13 & 2.75 & 0.2 & 38.3 & Plane & $\begin{array}{l}1.18 \\
0.98\end{array}$ & $\begin{array}{l}\text { Dry } \\
\text { Saturated }\end{array}$ & $\begin{array}{l}\text { Stable } \\
\text { Fail }\left(8.3 \mathrm{~m}^{\mathrm{a}}\right)\end{array}$ \\
\hline Ocp14 & 2.74 & 0 & 48.2 & Wedge & $\begin{array}{l}2.18 \\
1.47\end{array}$ & $\begin{array}{l}\text { Dry } \\
\text { Saturated }\end{array}$ & $\begin{array}{l}\text { Stable } \\
\text { Stable }\end{array}$ \\
\hline Ocp15 & 2.76 & 0.2 & 37.1 & Wedge & $\begin{array}{l}1.41 \\
0.89\end{array}$ & $\begin{array}{l}\text { Dry } \\
\text { Saturated }\end{array}$ & $\begin{array}{l}\text { Stable } \\
\text { Fail }\left(14.7 \mathrm{~m}^{\mathrm{a}}\right)\end{array}$ \\
\hline
\end{tabular}

\footnotetext{
${ }^{\mathrm{a}}$ Failure thickness.
}

develop, with elevated pore-water pressures in the substrate, and contributed directly to the occurrence of the landslide. Such a failure had not been expected at this location because the area is underlain by strong volcanic rocks. The relatively low strength of the tuffaceous conglomerate located below the lava flow (Fig. 3A) seems to have contributed to the large landslide that induced the debris flow.

Moreover, the geometry of bedrock discontinuities was found to exert an important control on the location of the landslides. Despite the high intact rock strength having friction angle more than $30^{\circ}$, the landslides occurred in areas where the entire rock mass had been weakened through the infiltration of water into regularly spaced bedrock discontinuities. Indeed, we have calculated that the safety factor for some saturated rock slopes fell below 1.0.

The debris flow appears to have occurred through multiple processes. Runoff within the catchment was mixed with sediment from the large landslides, transforming them into the debris flow. This mechanism has been suggested elsewhere by Montgomery et al. (2000) and Marchi et al. (2002). Subsequently, the size of the debris flow was probably augmented by sediment supply from the collapse of the sidewalls along the debris flow channel. However, the sediment budget estimation in Table 1 suggests that the majority of the sediment deposited in the lowermost reach came from the upper reach rather than the middle reach. This suggests that not a set of small landslides but a large- scale landslide is often needed to induce a catastrophic debris flow.

We also note that prior to the debris flow, there was only a small amount of sediment on the bed of the Sanho stream. This fact may have led any engineering assessment to conclude that the likelihood of a debris flow in the channel was low, since an insufficient amount of debris had accumulated. However, the single large landslide induced the debris flow that suddenly changed the river condition. Our study has revealed that, in order to quantify the risk and likely severity of mass movements in steep mountain regions, it is necessary to consider the stability of possible initial source regions and to assess the potential with which mass failures of one type (e.g., landslides) can be converted into those of another (e.g., debris flows).

\section{Conclusions}

The November 2000 landslides in the study area were triggered by a severe rainstorm of $370 \mathrm{~mm}$ in less than one day. Intense rainfall caused groundwater to infiltrate through the volcanic bedrock material along the fractures in the exfoliated zones. Consequently, the tuffaceous conglomerate and the weathered lava became saturated with water in some places and slopes there became unstable. The largest landslide in the upper reach mobilized debris as a landslide mass and it flowed down with water along the stream channel as a debris flow. 
The rapidly enlarging debris flow eroded the stream sidewalls but at the same time left some sediment on the riverbed, until it stopped in the downstream area. The accumulated deposits, in addition to those dislodged from valley sides during the storms, provided a source for future debris flows triggered by rainfall.

\section{Acknowledgements}

This work was support by the National Science Council, ROC. The authors would like to thank Prof. M. L. Lin, Dr. C.S. Wu and Mr. D.C. Lai for their critical suggestion, Prof. K. Thompson for revising the article and Ms. C.M. Yu for redrawing the diagram. Two reviewers, Prof. M. Soldati and Prof. G.R. Whittecar, provided constructive comments are gratefully appreciated. We thank Dr. T. Oguchi for many helpful suggestions which have improved the clarity of the paper.

\section{References}

Anderson, S.A., Sitar, N., 1995. Analysis of rainfall-induced debris flows. J. Geotech. Eng. 121, 544-552.

Brown, E.T., 1981. Rock Characterization, Testing, and Monitoring: ISRM Suggested Methods. Pergamon Press, Oxford. 211 pp.

Central Weather Bureau, 2003. Historical typhoon data: http://www. cwb.gov.tw/V4/typhoon/history/typhoon-history.htm.

Chang, J.C., 1996. Natural hazards in Taiwan. GeoJournal 38, 251-257.

Chen, H., Su, D.I., 2001. Geological factors for hazardous debris flows in Hoser, central Taiwan. Environ. Geol. 40, 1114-1124.

Chen, C.H., Wu, Y.J., 1971. Volcanic geology of the Tatun geothermal area, northern Taiwan. Proc. Geol. Soc. China 14, 5-20.

Chen, R.H., Lin, M.L., Chen, H., 1995. Mechanism of initiation of debris flow. In: Cheng, F.Y., Shew, F.S. (Eds.), Urban Disaster Mitigation. Elesevier, Oxford, pp. 231-243.

Chen, H., Chen, R.H., Lin, M.L., 1999. Initiation of the Tungmen debris flow, Eastern Taiwan. Environ. Eng. Geosci. 5, 459-473.

Dadson, S.J., Hovius, N., Chen, H., Dade, B.W., Lin, J.C., Hsu, M.L., Lin, C.W., Horng, M.J., Chen, T.C., Milliman, J., Stark, C.P., 2004. Earthquake-triggered increase in sediment delivery from an active mountain belt. Geology 32, 733-736.
Dai, F., Lee, C.F., Wang, S., 1999. Analysis of rainstorm-induced slide-debris flows on natural terrain of Lantau Island, Hong Kong. Eng. Geol. 51, 279-290.

Fleming, R.W., Ellen, S.D., Algus, M.A., 1989. Transformation of dilative and contractive landslide debris into debris flows an example from Marin County, California. Eng. Geol. 27, 201-223.

Guzzetti, F., Cardinali, M., Reichenbach, P., Cipolla, F., Sebastiani, C., Galli, M., Salvati, P., 2004. Landslides triggered by the 23 November 2000 rainfall event in the Imperia Province, Western Liguria, Italy. Eng. Geol. 73, 229-245.

Hansen, A., 1984. Landslide hazard analysis. In: Brunsden, D., Prior, D.B. (Eds.), Slope Instability. John Wiley \& Sons, New York, pp. 523-602.

Ho, C.S., 1986. An Introduction to the Geology of Taiwan: Explanatory Text of the Geologic Map of Taiwan. The Ministry of Economic Affairs, Republic of China. 164 pp.

Hoek, E., Bray, J., 1981. Rock Slope Engineering. The Institution of Mining and Metallurgy, London, pp. 150-198.

Hoek, E., Brown, E.T., 1997. Practical estimates of rock mass strength. J. Rock Mech. Mining Sci. 34, 1165-1186.

Hung, J.J., Lee, C.C., Lin, M.L., 2002. Tsao-Ling rockslides, Taiwan. In: Evans, S.G., DeGraff, J.V. (Eds.), Catastrophic Landslides: Effects, Occurrence, and Mechanisms. Colorado Geol. Soc. Am. Rev. Eng. Geology, vol. XV, pp. 91-115.

Iverson, R.M., Reid, M.E., LaHusen, R.G., 1997. Debris flow mobilization from landslides. Annu. Rev. Earth Planet. Sci. 25, $85-138$

Keefer, D.K., Wilson, R.C., Mark, R.K., Brabb, E.E., Brown III, W. M., Ellen, S.D., Harp, E.L., Wieczorek, G.F., Alger, C.S, Zatkin, R. S., 1984. Real-time landslide warning during heavy rainfall. Science 238, 921-925.

Marchi, L., Arattano, M., Deganutti, A.M., 2002. Ten years of debrisflow monitoring in the Moscardo Torrent (Italian Alps). Geomorphology 46, 1-17.

Montgomery, D.R., Schmidt, K.M., Greenberg, H.M., Dietrich, W.E., 2000. Forest clearing and regional landsliding. Geology 28, 311-314.

Petley, D.N., Bulmer, M.H., Murphy, W., 2002. Patterns of movement in rotational and translational landslides. Geology 30, 719-722.

Priest, S.D., 1992. Discontinuity Analysis for Rock Engineering. Chapman Hall, London. 420 pp.

Rib, H.T., Liang, T., 1978. Recognition and identification. In: Schuster, R.L., Krizek, R.L. (Eds.), Landslides: Analysis and Control. Spec. Rep., vol. 176. National Academy of Sciences, Washington, D.C, pp. 34-80.

Selby, M.J., 1987. Rock slopes. In: Anderson, M.G., Richards, K.S. (Eds.), Slope Stability. John Wiley \& Sons, New York, pp. 475-504. 